\title{
NORMA CONSTITUCIONAL INCONSTITUCIONAL? O CURIOSO CASO DO ART. 5, XXXI E DO ART. 227, § 6º DA CONSTITUIÇÃO FEDERAL DE 1988
}

\author{
UNCONSTITUTIONAL CONSTITUTIONAL NORMS? THE CURIOUS CASE OF \\ ARTICLE $5^{\text {TH }}$, CLAUSE XXXI, AND ARTICLE 227, § 6, OF THE 1988 BRAZILIAN \\ CONSTITUTION
}

\author{
Paul Hugo Weberbauer* \\ Liane de Medeiros Santiago Ramos**
}

\begin{abstract}
RESUMO
O artigo é uma tentativa de analisar a curiosa relação entre o princípio constitucional da lei mais favorável adotado em matéria de sucessão de bens de estrangeiros situados no Brasil (CF, art. $5^{\circ}$, XXXI) e o princípio da igualdade absoluta entre os filhos (art. 227, $\S 6^{\circ}$ ), como um caso de norma constitucional inconstitucional na Constituição Federal de 1988. Procura-se compreender o surgimento da temática da inconstitucionalidade das normas constitucionais, em especial a teoria de Otto Bachof e a posição no Brasil do Supremo Tribunal Federal (STF) na Ação Direta de Inconstitucionalidade (ADIn) $n^{\circ}$. 815-3 DF. Analisam-se ainda a incorporação do princípio da lei mais favorável em matéria de sucessão como um direito fundamental e a inovação trazida pelo texto constitucional de 1988 na positivação do princípio da igualdade absoluta entre os filhos para, ao final, tentar estabelecer os elementos que tornam essa situação curiosa um caso de norma constitucional inconstitucional no Brasil.
\end{abstract}

\section{PALAVRAS-CHAVE}

Inconstitucionalidade de normas constitucionais. Igualdade dos filhos. Princípio da lei mais favorável. Direito internacional privado.

\begin{abstract}
The paper tries to analyze the curious relationship between the constitutional most favorable law principle adopted in relation to the succession of foreign assets located in Brazil (art. $5^{\circ}, \mathrm{cl}$. XXXI) and the Equal Protection Clause as guiding rule for Children's Legitimacy (art. 227, § 6), as a case of unconstitutional constitutional norm in the Brazilian Federal Constitution. It seeks to understand the emergence of the theory of unconstitutional constitutional norms, paying special attention to the theory of Otto Bachof and to the manifested position of the Brazilian Supreme Federal Court (STF) in the Direct Unconstitutional Action (ADIn) \#815-3 DF. It also seeks to understand how the most favorable law principle became a fundamental right in the Brazilian constitutional tradition as well as the consequences of the application of Equal Protection Clause to Children's Legitimacy by the current Constitution. At the end, it will try to indicate the elements that make this curious situation a case of unconstitutional constitutional norm in Brazil.

\footnotetext{
* Graduado em Direito pelo Centro Universitário de Vila Velha (2004), mestre em Direito pela Universidade Federal de Pernambuco (2006) e doutor em Direito pela Universidade Federal de Pernambuco (2011). Professor adjunto da Universidade Federal de Pernambuco (Recife, PE, Brasil).E-mail: phweberbauer@hotmail.com

** Bacharelanda em Direito pela Faculdade de Direito do Recife - UFPE (Recife, PE, Brasil). E-mail: lianedemedeiros@hotmail.com
} 


\section{KEYWORDS}

Unconstitutional constitutional norms. Equal Protection Clause (Children's Legitimacy). Most favorable law principle. Conflict of law (private international law).

\section{INTRODUÇÃO}

A Constituição Federal (CF) de 1988 estabeleceu uma grande inovação no direito de família brasileiro ao determinar a igualdade absoluta dos filhos, rompendo a tradição civilista de estabelecer diferença de tratamento a eles. Em especial, baniu a ideia de existirem filhos legítimos e ilegítimos. Ocorre que o mesmo texto constitucional inovador optou por manter a tradição no direito internacional privado, ao estabelecer o princípio da lei mais favorável para os filhos brasileiros quando se abre sucessão sobre bens imóveis de estrangeiros situados no Brasil (art. 5º XXXI, da CF).

O presente estudo procura analisar e explicar o tratamento diferenciado que a Constituição confere ao filho brasileiro em matéria de sucessão à vista do princípio da igualdade dos filhos, ambos positivados no texto constitucional. Seria um caso de existência de uma norma constitucional inconstitucional? E qual seria a norma dotada de inconstitucionalidade?

Com o objetivo de tentar responder a esses questionamentos, o estudo inicia com a teoria das normas constitucionais inconstitucionais e sua recepção no Brasil. Parte-se da análise da teoria formulada pelo jurista alemão Otto Bachof em 1951, não só compreendendo sua ideia central, mas também a realidade constitucional que a criou: a natureza sui generis da Lei Fundamental alemã de 1949. Posteriormente, procede-se à sua influência no Brasil - mais precisamente, a posição expressa pelo Supremo Tribunal Federal (STF) sobre esse assunto na Ação Direta de Inconstitucionalidade (ADIn) $n^{\circ} .815-3$ DF.

No segundo momento é analisada a incorporação do princípio da lei mais favorável em matéria de sucessão de bens de estrangeiros situados no Brasil, procurando compreender a tradição, criada na legislação brasileira, de transformar um princípio cosmopolita do direito internacional privado em um direito fundamental do filho brasileiro - da qual o art. 5º XXXI, da CF é a manifestação legislativa mais recente.

No terceiro momento, foca-se na grande inovação da CF de 1988 em matéria de direito da família: a positivação do princípio da igualdade absoluta entre os filhos, insculpida no art. 227, § $6^{\circ}$, da CF, procurando entender a profundidade de tal inovação, bem como sua correlação com o filho estrangeiro.

Finalmente, analisa-se, ao interpretar sistematicamente as previsões constitucionais, a situação curiosa criada pela tradição mantida no art. $5^{\circ}, \mathrm{XXXI}$, da CF, com a inovação do art. 227, § Revista da Faculdade de Direito - UFPR, Curitiba, vol. 61, n. 1, jan./abr. 2016, p. 115 - 144 
$6^{\circ}$, da CF, utilizando como vetor de análise a Teoria de Bachof, para determinar os fatores que possibilitam e os que impedem a configuração de uma hipótese de inconstitucionalidade de norma constitucional na Constituição brasileira de 1988.

Quanto à metodologia, foi utilizado o método dedutivo, coletando-se dados das fontes legislativas, jurisprudenciais e doutrinárias para a criação das premissas que, conjugadas, permitem a conclusão.

Isso significa que, no primeiro momento, procura-se compreender e contextualizar historicamente as teorias e princípios, bem como sua inserção no pensamento jurídico, para, então, na sua correlação, estabelecer a aplicabilidade ou não do marco teórico adotado para a situação curiosa entre os dois princípios positivados na Carta Magna brasileira de 1988. Trata-se do método histórico-crítico, que, privilegiando a investigação textual, procura estabelecer um fundamento para a extração de um posicionamento crítico sobre o tema.

\section{A INCONSTITUCIONALIDADE DE NORMAS CONSTITUCIONAIS: A TEORIA DE BACHOF E A ADIN Nº. 815-3 DF}

\subsection{A NATUREZA SUI GENERIS DA LEI FUNDAMENTAL ALEMÃ DE 1949}

Como se sabe, no caso alemão a jurisprudência dos valores (Wertungsjurisprudenz) serviu para equalizar a tensão que se produziu com a outorga da Grundgesetz pelos aliados, em 1949. Com efeito, nos anos que sucederam a consagração da lei fundamental houve um esforço considerável por parte do Bundesverfassungsgericht para legitimar uma Carta que não tinha sido constituída com a ampla participação do povo alemão. Daí a afirmação de um jus distinto da lex, ou seja, a inovação de argumentos que permitisse ao Tribunal recorrer a critérios decisórios que se encontravam fora da estrutura rígida da legalidade. A referência a valores aparece, assim, como mecanismo de "abertura” de uma legalidade extremamente fechada (STRECK, 2011, p. 9).

O ponto de partida para compreender a questão das Verfassungswidrige Verfassungsnormen (normas constitucionais inconstitucionais) proposta pelo jurista Otto Bachof em 1951 é entender que a Lei Fundamental de Bonn de 1949 (doravante Grundgesetz) não é uma constituição em sentido estrito. Não se trata do produto de um processo legislativo soberano e ilimitado - ela não é resultado de um poder constituinte originário nos moldes que a teoria constitucional concebe.

A constatação não decorre da força normativa ou do texto da Grundgesetz, mas sim da realidade em que ela foi elaborada, da qual se podem destacar dois fatores históricos importantes: 
(1) o Besatzungsstatut (Estatuto de Ocupação) e (2) a ausência de participação popular direta na sua elaboração.

A Alemanha de 1949 não era um Estado soberano, mas sim um Estado dividido em quatro zonas de ocupação, cada zona sob responsabilidade de uma das potências ocidentais vencedoras da Segunda Guerra Mundial. Basicamente, cada zona tinha uma estrutura jurídica submissa à potência ocupante, havendo a iniciativa isolada dos Estados Unidos da América em promover a reintegração das três zonas ocidentais para recriação do Estado alemão - iniciativa que faria nascer a República Federativa da Alemanha (Alemanha Ocidental) e a República Democrática da Alemanha (Alemanha Oriental); esta, fruto da resposta soviética à iniciativa estadunidense.

Sob a ótica jurídica, essa situação histórica leva à conclusão de que a Grundgesetz é, primeiro, produto do legislador alemão ocidental e, segundo, esse legislador não gozava de poderes ilimitados para a elaboração do texto constitucional, pois obrigatoriamente estava sujeito à imposição das potências aliadas, por via do Alto Comissariado Aliado, do Besatzungsstatut, documento que serviria de guia para a integração das zonas ocidentais, outorgado em 12 de maio de 1949 e que previa, em seu item 5:

5. Jede Änderung des Grundgesetzes bedarf vor ihrem Inkrafttreten der ausdrücklichen Genehmigung der Besatzungsbehörden. Länderverfassungen, Änderungen dieser Verfassungen, alle sonstige Gesetzgebung und alle Abkommen zwischen dem Bund und ausländischen Regierungen treten 21 Tage nach ihrem amtlichen Eingang bei den Besatzungsbehörden in Kraft, es sei denn, daß diese sie vorher vorläufig oder endgültig ablehnen. Die Besatzungsbehörden werden gesetzgeberische Maßnahmen nicht ablehnen, es sei denn, daß sie ihrer Ansicht nach mit dem Grundgesetz, mit einer Länderverfassung, mit der Gesetzgebung oder den sonstigen Direktiven der Besatzungsbehörden oder mit Bestimmungen dieses Statuts unvereinbar sind, oder daß diese Maßnahmen die Grundziele der Besatzung ernstlich gefährden ${ }^{1}$ (BAYERISCHE STAATSBIBLIOTHEK, 1949).

Havia assim razão à própria afirmação de Otto Bachof, em 1951, de que “o poder constituinte da Federação e dos Estados federados subsiste por enquanto apenas no quadro do Estatuto da Ocupação e do Direito da ocupação” (BACHOF, 2008, p. 15). Em síntese, a Grundgesetz não se enquadra no conceito tradicional de constituição devido ao fato de existir um direito acima dela: uma espécie de metadireito, manifesto pelo direito de ocupação por parte das potências aliadas ocidentais, e cujas tradição e existência estão atreladas ao direito das gentes.

\footnotetext{
1 “5. Qualquer modificação da Lei Fundamental necessita, antes de sua vigência, de autorização expressa da autoridade de ocupação. As constituições estaduais, as alterações dessas constituições, todas as demais legislações e todos os acordos entre a Federação e governos estrangeiros entram em vigor 21 dias após sua recepção oficial pelas autoridades de ocupação, a menos que estas sejam previamente rejeitadas de forma temporária ou em definitivo. A autoridade de ocupação não irá rejeitar medidas legislativas, a menos que, em sua visão, sejam contrárias à Lei Fundamental, a uma constituição estadual, à legislação vigente ou a qualquer outra diretiva da autoridade de ocupação, ou que estejam em desconformidade com o presente Estatuto, ou que essa medida ameace os objetivos fundamentais da ocupação" (tradução nossa).
} 
A outra particularidade decorrente desse contexto histórico é a de que todo o processo legislativo que originou a Grundgesetz foi feito de forma indireta, isto é, não houve uma participação popular direta que conferisse legitimidade para a Grundgesetz ser considerada uma Verfassung (constituição, em alemão), pois “não foi o povo alemão que colocou as regras que nela se apresentavam” (STRECK; BARRETTO; OLIVEIRA, 2009).

Tal ausência de participação popular direta no processo de criação da Grundgesetz pode ser constatada até os dias de hoje, com a existência da Eingangsformel (fórmula de entrada) antecedente ao preâmbulo, na qual se lê:

Der Parlamentarische Rat hat am 23. Mai 1949 in Bonn am Rhein in öffentlicher Sitzung festgestellt, daß das am 8. Mai des Jahres 1949 vom Parlamentarischen Rat beschlossene Grundgesetz für die Bundesrepublik Deutschland in der Woche vom 16. bis 22. Mai 1949 durch die Volksvertretungen von mehr als Zweidritteln der beteiligten deutschen Länder angenommen worden ist.

Auf Grund dieser Feststellung hat der Parlamentarische Rat, vertreten durch seine Präsidenten, das Grundgesetz ausgefertigt und verkündet. Das Grundgesetz wird hiermit gemäß Artikel 145 Abs. 3 im Bundesgesetzblatt veröffentlicht: [...] $]^{2}$ (ALEMANHA, 1949).

A Eingangsformel continua existindo na Grundgesetz, tanto em sua versão de 1949 como na de 1990, expondo, de forma expressa, que o presente diploma legislativo é obra do Parlamentarischen Rat (Conselho de Estado criado pelas potências ocupantes em 1948), composto por 65 membros com voto e cinco membros sem, todo eleitos de forma indireta pelos parlamentos estaduais, cuja função era cuidar dos assuntos envolvendo as zonas ocidentais, e que foi dissolvido logo após a preparação para as primeiras eleições gerais na então Alemanha Ocidental, que ocorreram em 14 de agosto de 1949.

A Grundgesetz não foi propriamente promulgada, mas sim outorgada para o povo alemão ocidental.

Interessante notar que, mesmo com a reunificação da Alemanha em 1990, a Eingangsformel não foi retirada e nem alterada, mantendo-se sua redação original de 1949, enquanto o preâmbulo sofreu uma profunda alteração no texto de 1990, não só por causa da incorporação dos cinco estados federados orientais, mas também como cumprimento da missão estipulada no preâmbulo de 1949, de finalizar a unificação alemã, conforme o quadro comparativo:

\footnotetext{
2 “O Conselho Parlamentar confirmou em sessão pública, no dia 23 de maio de 1949 em Bonn, que a Lei Fundamental da República Federal da Alemanha, aprovada pelo Conselho Parlamentar no dia 8 de maio de 1949, tinha sido ratificada na semana de 16 a 22 de maio de 1949 pelos Parlamentos de mais de dois terços dos Estados alemães participantes. Baseando-se nesta confirmação, o Conselho Parlamentar, representado pelos seus Presidentes, sancionou e promulgou a Lei Fundamental. Assim sendo, e em obediência ao artigo 145 § 3, publique-se a Lei Fundamental no Diário Oficial da Federação” (ALEMANHA, 2011, tradução oficial pela Editora do Parlamento Alemão).
} 


\begin{tabular}{|c|c|}
\hline Preâmbulo original & Preâmbulo atual \\
\hline $\begin{array}{l}\text { Im Bewußtsein seiner Verantwortung vor } \\
\text { Gott und den Menschen, von dem Willen } \\
\text { beseelt, seine nationale und staatliche } \\
\text { Einheit zu wahren und als } \\
\text { gleichberechtigtes Glied in einem } \\
\text { vereinten Europa dem Frieden der Welt } \\
\text { zu dienen, hat das Deutsche Volk } \\
\text { in den Ländern Baden, Bayern, Bremen, } \\
\text { Hamburg, Hessen, Niedersachsen, } \\
\text { Nordrhein-Westfalen, Rheinland-Pfalz, } \\
\text { Schleswig-Holstein, Württemberg-Baden } \\
\text { und Württemberg-Hohenzollern, um dem } \\
\text { staatlichen Leben für eine Übergangszeit } \\
\text { eine neue Ordnung zu geben, um dem } \\
\text { staatlichen leben für eine Übergangszeit } \\
\text { eine neue Ordnung zu geben, kraft seiner } \\
\text { verfassungsgebenden Gewalt dieses } \\
\text { Grundgesetz der Bundesrepublik } \\
\text { Deutschland beschlossen. Es hat auch für } \\
\text { jene Deutschen gehandelt, denen } \\
\text { mitzuwirken versagt war. Das gesamte } \\
\text { Deutsche Volk bleibt aufgefordert, in } \\
\text { freier Selbstbestimmung die Einheit und } \\
\text { Freiheit Deutschlands zu vollenden } 3 \text {. } \\
\text { (ALEMANHA, 1949) }\end{array}$ & $\begin{array}{l}\text { Im Bewußtsein seiner Verantwortung vor } \\
\text { Gott und den Menschen, von dem Willen } \\
\text { beseelt, als gleichberechtigtes Glied in } \\
\text { einem vereinten Europa dem Frieden der } \\
\text { Welt zu dienen, hat sich das Deutsche } \\
\text { Volk kraft seiner verfassungsgebenden } \\
\text { Gewalt dieses Grundgesetz gegeben. } \\
\text { Die Deutschen in den Ländern Baden- } \\
\text { Württemberg, Bayern, } \\
\text { Brandenburg, Bremen, Hamburg, Hessen, } \\
\text { Mecklenburg-Vorpommern, } \\
\text { Niedersachsen, Nordrhein-Westfalen, } \\
\text { Rheinland-Pfalz, Saarland, Sachsen, } \\
\text { Sachsen-Anhalt, Schleswig-Holstein und } \\
\text { Thüringen haben in freier } \\
\text { Selbstbestimmung die Einheit und } \\
\text { Freiheit Deutschlands vollendet. Damit } \\
\text { gilt dieses Grundgesetz für das gesamte } \\
\text { Deutsche Volk }{ }^{4} \text {. (ALEMANHA, 1990) }\end{array}$ \\
\hline
\end{tabular}

\footnotetext{
3 “Consciente de sua responsabilidade perante Deus e os homens, movidos pela vontade de servir à paz do mundo, como membro com igualdade de direito de uma Europa unida, o povo alemão nos Estados de Baden, Baviera, Bremen, Hamburgo, Hesse, Baixa Saxônia, Renânia da Norte-Vestfália, Renânia-Palatinado, Schleswig-Holstein, WürttembergBaden e Württemberg-Hohenzollern, para manter a organização política durante o período de transição para uma nova ordem, por força de seu poder constituinte, outorga a presente Lei Fundamental da República Federal da Alemanha. Também atuando em nome daqueles alemães, aos quais foi negada a participação. Restando para o povo alemão, como um todo, o desafio de conseguir, em livre autodeterminação, a unidade e a liberdade de toda a Alemanha” (tradução nossa).
} 
Esses dois fatos históricos evidenciam a natureza sui generis da Grundgesetz, de modo a ficar manifesto que, ao propor uma teoria sobre normas constitucionais inconstitucionais, Otto Bachof estava preocupado com a ausência de legitimidade popular da Grundgesetz, situação que poderia gerar uma ausência de eficácia em suas disposições. Procurou com sua teoria conceber uma modalidade de controle de constitucionalidade que evitasse essa situação e que fosse tão amplo que pudesse controlar até mesmo as próprias normas constitucionais originárias (as quais, na Grundgesetz, nem eram tão originárias).

Em suma, a teoria de Bachof procura responder à questão acerca da possibilidade de ser declarada inconstitucional uma norma que contrarie algum tipo de "essência jurídica absoluta”, ou que infrinja “o próprio sistema interno do texto constitucional, de modo a permitir uma alteração significativa de seu conteúdo” (STRECK; BARRETTO; OLIVEIRA, 2009).

\subsection{A TEORIA DE BACHOF}

A teoria da inconstitucionalidade de normas constitucionais proposta por Bachof pode ser compreendida a partir de seus dois pilares principais: (1) a concepção de constituição e (2) a questão do direito metapositivo.

O primeiro pilar é própria concepção de constituição, concepção que pode ser separada em um sentido formal e um sentido material. No sentido formal, constituição se reduz às leis de disposições positivadas em determinado documento específico, cuja aprovação, denominação e reforma possuem ritos (procedimentos) próprios (BACHOF, 2010, p. 58). Normas constitucionais formais são normas que se tornaram constitucionais por capricho da maioria parlamentar; ou melhor, tornaram-se constitucionais não pelo seu conteúdo, mas sim por terem obedecido ao rito (procedimento) especial (BACHOF, 2010, p. 58).

No sentido material, a constituição alude, “en general, al conjunto de normas que regulan la constitución, las funciones y las competencias de los órganos superiores del Estado, las estructuras básicas estatales y la posición de los ciudadanos en el seno del Estado” (BACHOF,

\footnotetext{
4 “Consciente de sua responsabilidade perante Deus e os homens, movido pela vontade de servir à paz do mundo, como membro com igualdade de direitos de uma Europa unida, o povo alemão, em virtude do seu poder constituinte, outorgou-se a presente Lei Fundamental. Os alemães nos Estados de Baden-Württemberg, Baviera, Berlim, Brandemburgo, Bremen, Hamburgo, Hesse, Mecklemburgo-Pomerânia Ocidental, Baixa Saxônia, Renânia do NorteVestfália, Renânia-Palatinado, Sarre, Saxônia, Saxônia-Anhalt, Schleswig-Holstein e Turíngia consumaram, em livre autodeterminação, a unidade e a liberdade da Alemanha. A presente Lei Fundamental é válida, assim, para todo o povo alemão” (ALEMANHA, 1990, tradução oficial pela editora do Parlamento alemão).
} 
2010, p. 59). Na acepção material, a constituição ultrapassa a mera positivação e estabelece uma relação com o direito metapositivo, de modo a possibilitar uma distinção entre a obrigatoriedade jurídica e a positivação, bem como a associar o plano da validade com a ideia de legitimação:

\begin{abstract}
El problema fundamental de la validez de una Constitución no solo en el sentido de supra positividad, sino también, y sobre todo, en el sentido de su obligatoriedad jurídica - por tanto, subsiste. Además, nuevamente cuestión jurídico-material sobre la validez de la Constitución conforme a las normas de derecho metapositivo no ha de ser confundida cuestión sobre la competencia judicial, acaso exista, lo relativo al control de constitucionalidad (BACHOF, 2010, p. 61).
\end{abstract}

O arcabouço normativo da constituição ultrapassa o texto positivado, incluindo em seu bojo todo o conjunto normativo não positivado - por exemplo, princípios, costumes e valores -, gerando a ideia da existência de um direito metapositivo.

A existência do direito metapositivo é o segundo pilar central do pensamento de Bachof e o mais problemático de ser compreendido. Direito “metapositivo” não deve ser confundido com direito natural - deve ser compreendido como uma saída argumentativa, encontrada por Bachof, para denominar aquele conjunto normativo que não se reduz ao direito positivo, mas também não adentra na inexatidão existente na expressão direito natural.

Dessarte, o direito metapositivo deve ser tratado como uma ordem objetiva criada a partir da ideia de obrigatoriedade, e não de leis; ou melhor, na convicção de um povo de que a carta é válida não só por seu parâmetro formal (vigência), mas também por sua aceitação social (efetividade) e conforme a ética (fundamentos) (ESTRELLA, 2015).

Recorrendo a uma analogia grosseira, o direito metapositivo pode ser associado à ideia de ordem objetiva criada a partir da consciência jurídica geral do povo, devido ao fato de ser o povo o verdadeiro titular do poder constituinte, e que “obedece a padrões e modelos de condutas espirituais, culturais, éticos e sociais radicados na consciência jurídica geral da comunidade” (CANOTILHO, 2002, p. 81).

Por consequência, uma afronta de uma norma positivada contra a consciência jurídica geral do povo (direito metapositivo) resulta na não obrigatoriedade da norma em conflito, gerando, portanto, sua inconstitucionalidade, pois esse direito metapositivo é integrante da constituição em seu sentido material.

Desse modo, tentou Bachof - até mesmo para evitar a rejeição doutrinária ao termo direito natural - emprestar-lhe um caráter objetivo, tratando deste como um verdadeiro direito supralegal, com vigência, e não somente amparo, em disposições morais. Somente a violação deste direito supralegal pela constituição, em norma estatuída pelo poder constituinte originário, poderia levar à declaração de inconstitucionalidade (FERNANDES, 2015). 
Bachof tinha consciência de que muitas normas inseridas na Grundgesetz só o foram por mera força formal, por capricho do legislador, e que por essa situação estariam sujeitas ao controle de constitucionalidade, mesmo sendo consideradas normas constitucionais originárias.

O grande problema nessa dicotomia formal/material utilizada por Bachof é que, no Brasil e por falta da devida contextualização histórica, acabou sendo gerada uma simplificação equivocada, de que normas constitucionais materiais seriam hierarquicamente superiores às normas constitucionais formais (ESTRELLA, 2015).

O equívoco reside, em primeiro lugar, na não atenção de que, no próprio pensamento de Bachof, a dicotomia material/formal não é rígida, tanto que o autor afirma existirem normas constitucionais formais com conteúdo material (BACHOF, 1994, p. 48); e, em segundo lugar, o próprio Bachof não acreditava que o critério hierárquico por si pudesse servir de parâmetro para determinar a possibilidade do controle de constitucionalidade de normas constitucionais, como explica:

\begin{abstract}
A meu ver nenhuma diferença faz aqui que essas normas constitucionais sejam importantes ou menos importantes, não me parecendo possível considerar inconstitucional uma norma da Constituição de grau inferior, em virtude de uma pretensa incompatibilidade com o «conteúdo de princípio da Constituição» (GIESE), desde que este conteúdo de princípio da constituição seja ainda produto de uma autónoma criação de Direito. Não pode aqui falar-se de uma «decisão de princípio» e de uma «contradição do legislador constitucional consigo mesmo» (KRÜGER), mas sim, quando muito, de regra e excep̧̧ão (BACHOF, 1994, p. 57, grifo do autor).
\end{abstract}

Nossa opinião é a de que a dicotomia de Bachof é voltada para a elaboração de uma dosimetria axiológica que possibilite a realização do controle de constitucionalidade de normas constitucionais por parte do Judiciário. A dosimetria axiológica é que seria o parâmetro de controle de constitucionalidade, e não a simples hierarquia entre as normas.

Afirma-se que a dicotomia em tela tem como finalidade maior possibilitar apreender o conteúdo da norma e classificá-lo de forma a estabelecer possíveis regras posteriores de hierarquia, mas nunca a de servir de critério único para estabelecer dominância de uma norma sobre a outra no texto constitucional.

Fundamenta-se essa afirmação quando se verifica a finalidade de Bachof em conferir maior campo de atuação ao Poder Judiciário, privilegiando a atuação e o papel do Tribunal Constitucional Federal alemão, e não de estabelecer um controle de constitucionalidade de normas constitucionais como um instrumento de arbítrio por parte dos juízes. Justamente para evitar esse arbítrio é que existe a ideia de direito metapositivo e sua associação com a legitimidade/obrigatoriedade na consciência jurídica do povo (incluídas tanto as etapas de criação quanto de aplicação do direito); 
sendo este (direito metapositivo) o fundamento do controle, e não a consciência do juiz (BACHOF, 2010, p. 64).

\title{
1.3 A ADIN Nº. 815-3 E A POSIÇÃO DO SUPREMO TRIBUNAL FEDERAL
}

No Brasil o tema da inconstitucionalidade de normas constitucionais ganhou destaque quando do julgamento da ADIn $n^{\circ}$. 815-3 DF, na qual o Governo do Estado do Rio Grande do Sul pleiteou a declaração de inconstitucionalidade dos $\S \S 1^{\circ}$ e $2^{\circ}$ do art. 45 da $\mathrm{CF}$, que regulam sobre o número mínimo de representantes de cada estado e território na Câmara dos Deputados.

Argumentou o Governo do Estado do Rio Grande do Sul que os referidos dispositivos constitucionais seriam inconstitucionais por infringirem os princípios constitucionais da igualdade (art. $5^{\circ}$ ), da igualdade do voto (art. 14), do exercício do poder pelo povo (art. $1^{\circ}$, parágrafo único), da cidadania (art. $1^{\circ}$, II) e da democracia (art. $1^{\circ}$ ) (BRASIL, 1996).

Como fundamento jurídico, invocou-se a teoria de Bachof, interpretando-a de modo a conceber uma hierarquia em sede de constituição entre as normas constitucionais materiais (normas-princípios) e as normas constitucionais formais (normas-disposição), alegando-se que as normas-princípios seriam hierarquicamente superiores às normas-disposição e, portanto, estas últimas seriam inconstitucionais (BRASIL, 1996).

Diante do pleito, optou o STF por não conhecer da ação, por impossibilidade jurídica do pedido, conforme posição do Relator Moreira Alves:

\begin{abstract}
Não podendo, pois, o Supremo Tribunal, em controle de constitucionalidade difuso ou concentrado, fiscalizar o Poder Constituinte originário, quer em face do direito suprapositivo não positivado na Constituição, quer diante do direito suprapositivo positivado na Carta Magna, que com base em normas constitucionais que seriam de grau superior ao das demais, não pode ele, com base no princípio da igualdade [...] e de seus consectários segundo os termos da inicial, conhecer da presente ação direta, por impossibilidade jurídica do pedido (BRASIL, 1996).
\end{abstract}

A impossibilidade jurídica do pedido foi baseada em dois fundamentos: o primeiro, de que seria irrelevante a distinção entre material e formal nas normas contidas em uma constituição escrita 5 ; e, o segundo, na impossibilidade de um órgão de controle criado pela própria constituição poder realizar o controle sobre o poder originário que o criou (BRASIL, 1996).

O primeiro fundamento está associado diretamente à ideia de unidade da constituição, unidade no sentido de que não pode existir um escalonamento hierárquico entre as normas

\footnotetext{
${ }^{5}$ Não nos referimos à inconstitucionalidade formal como aquela em que a norma elaborada pelo poder constituinte derivado apresenta falha no procedimento de aprovação perante as casas legislativas, mas sim à classificação de conteúdo feita por Bachof.
} 
existentes na constituição pelo simples fato de o poder constituinte reformador não ter poder ilimitado, não estando apto para realizar uma revisão constitucional completa, e muito menos alterar o que foi estabelecido pelo poder constituinte originário, tanto no plano dos valores quanto no plano normativo.

Em síntese, tal fundamento remonta à doutrina nascida com Emmanuel J. Sieyès, para quem o poder ilimitado restaria na vontade nacional (volonté national) e não no governo (gouvernement), pois o primeiro estaria ligado diretamente ao direito natural e, portanto, seria ilimitado, enquanto que o último estaria limitado pela constituição, não possuindo um poder real, mas sim o poder derivado do poder real, o qual estaria na vontade da nação, do povo (SIEYÉS, 1780, p. 113-114).

Dessarte, conclui-se que tanto o governo quanto os órgãos criados pela constituição só podem atuar nos limites conferidos por esta, daí a constatação de que o poder constituinte derivado (ou reformador) é um poder limitado e, por consequência, de que não cabe ao órgão jurisdicional realizar o controle de constitucionalidade das normas constitucionais originárias da carta magna que o criou e investiu de poder jurisdicional. Só haveria tal possibilidade se a própria constituição, por via de norma constitucional originária, expressamente determinasse tal competência.

Na esteira desse pensamento, acrescenta-se ainda a tradição formalista-legalista da jurisprudência brasileira, a qual acaba por resultar na concepção de que a constituição é o “último fundamento e critério positivo vigente de pertinência e validade das demais normas integrantes do ordenamento” (NEVES, 1988, p. 62), pensamento gerador de uma poderosa barreira na mentalidade jurídica brasileira em conceber a ideia de um direito metapositivo, bem como de utilizar essas ideias como parâmetro de apreciação da ordem jurídica posta. Sem essa concepção de direito metapositivo, resta impossível o controle de normas constitucionais originárias.

Importante salientar que o apego no Brasil à tradição formalista-legalista é compreensível, devido ao fato de a Constituição Federal de 1988 ser produto de um poder constituinte originário, não sofrendo de ausência de legitimidade popular, sendo uma constituição propriamente dita.

A inexistência, na história brasileira, de experiência similar à passada pela Alemanha pósGuerra não gerou fatores ou eventos que cogitassem a necessidade ou, até mesmo, utilidade para realizar o controle constitucional, baseado na legitimidade, de normas promulgadas pelo próprio poder constituinte originário.

Em suma, pela jurisprudência brasileira resta inaplicável a teoria de inconstitucionalidade de normas constitucionais, por força do princípio da unidade da constituição e da incompetência do Poder Judiciário para fiscalizar os atos do poder constituinte originário. 


\section{O PRINCÍPIO DA LEI MAIS FAVORÁVEL E O INCISO XXXI DO ARTIGO 5 DA CF}

Tomando a diversidade legislativa, o direito internacional privado consagrou a ideia de que a sucessão seria uma área na qual a teoria colisional trabalharia com dois grandes elementos de conexão: a lex patriae e a lex rei sitae, os quais seriam os "jogadores" que determinariam o enquadramento de determinada sucessão em determinado regime jurídico nacional (MIRANDA, 1935, p. 267-268).

No Brasil, o tratamento legislativo ${ }^{6}$ do direito internacional privado tem como destaque, para a sucessão, a previsão do art. 14 do capítulo de Introdução do Código Civil de 1916 (ICC/1916), o qual determinava:

Qualquer que seja a natureza dos bens e o país onde se achem, guardado o disposto neste Código acerca das heranças vagas abertas no Brasil, obedecerão a lei nacional do falecido; se este, porém, era casado com brasileira, ou tiver deixado filhos brasileiros, ficarão sujeitos à lei brasileira (BRASIL, 1916).

Consagrado estava o elemento de conexão da lex patriae. No primeiro momento, na figura da nacionalidade do de cujus, e, no segundo momento, na nacionalidade brasileira do cônjuge brasileiro ou dos filhos brasileiros. Tratava-se de uma norma unilateral, não estabelecendo nenhum favorecimento, mas sim uma regra geral (lei do local de nacionalidade do falecido) e uma regra específica (lei brasileira se casado com cônjuge brasileiro ou se tivesse filhos brasileiros). Era o sistema regra-exceção, sob égide de uma legislação que permitia a discriminação entre filhos.

A tradição de apego a lex patriae como elemento de conexão para as sucessões no sistema colisional brasileiro acabou sendo rompida com o advento da Constituição de 1934, que, em seu art. 134, dispôs que “a vocação para suceder em bens de estrangeiros existentes no Brasil será regulada pela lei nacional em benefício do cônjuge brasileiro e dos seus filhos, sempre que não lhes seja mais favorável o estatuto do de cujus” (BRASIL, 1934).

Portanto, foi por força constitucional que a regra do art. 14 da ICC/1916 acabou sendo alterada, inaugurando a tradição de estabelecer a regra geral do lex situs, porém aplicando-se, para

\footnotetext{
${ }^{6}$ Importa lembrar que o Código Civil de 1916 foi o primeiro a estabelecer um elemento de conexão para a questão sucessória; porém, não foi o primeiro a lidar com a questão do estrangeiro na sucessão. A questão da herança de estrangeiros já estava presente na Consolidação de Leis Civis de 1858, elaborada por Teixeira de Freitas, a qual, em seu art. 1.260, definia que "A disposição do art. 34, quanto á heranças de estrangeiros, será observada á respeito dos subditos daquellas Nações, com as quaes, em virtude de accôrdo, fôr estabelecida a reciprocidade por meio de Notas reversaes, accedendo Decreto do Govêrno” (BRASIL, 1876, p. 725). Em linhas gerais, quando a herança de um estrangeiro não tinha herdeiros no Brasil para dela tomarem posse (com ou sem testamento - art. 34), ou quando a herança era jacente, a matéria deveria ser regulada pelo direito das gentes e, por consequência, com base no princípio da reciprocidade. Caso não houvesse tal regulamentação, ainda assim havia a necessidade de se informar o cônsul do país do de cujus, para que participasse do inventário (art. 1.262).
} 
os casos de cônjuge brasileiro, o princípio da lei mais favorável - princípio alargado, pela doutrina da época, ao filho brasileiro.

Trata-se de regra - "conteúdo lex situs" - portanto aplicada aos bens sitos - aí ditos "existentes" - no Brasil. O legislador brasileiro, como legislador do Estado em que estão localizados os bens, ligou a sucessão à sua lei. Tinha competência para fazê-lo. Porém não o fez em todos os casos. Apenas entendeu proceder à ligação quando o de cujus estivesse em certa relação para com certos brasileiros. Quer dizer: quando fosse casado com brasileira, ou tivesse filho brasileiro (MIRANDA, 1935, p. 268-269).

Curiosamente, a regra constitucional de 1934 acabou por estabelecer certa equidade entre os filhos legítimos e os filhos ilegítimos (adulterinos), devido ao fato de a regra expressa não levar em consideração o tipo de vínculo entre o estrangeiro e o filho brasileiro, mas tão somente o fato de, para gozar da regra da lei mais favorável, ser filho e ser brasileiro (MIRANDA, 1935, p. 269).

Também é curioso notar que é com o texto constitucional de 1934 que se inicia a tradição legislativa de se associar o princípio da lei mais favorável, em matéria de sucessão, como sendo uma espécie de direito fundamental individual do cônjuge brasileiro que, com o art. 165 da Constituição de 1946 (BRASIL, 1946), passa a ser estendido ao filho brasileiro. Tradição que se manteve no art. $150 \S 33$ da Constituição de 1967 (BRASIL, 1967) e, atualmente, no art. 5º, XXXI da Constituição de 1988 (BRASIL, 1988) .

A mudança operada na Constituição de 1934 e mantida na Constituição de 1937, de substituir a lex patriae pela lex situs somada ao princípio mais favorável ao cônjuge brasileiro e aos filhos do casal, consolidou-se com a Lei de Introdução ao Código Civil de 1942 (renomeada em 2010, pela Lei ${ }^{0}$. 12.376, para Lei de Introdução às Normas do Direito brasileiro [LINDB]), a qual repetia ipsis litteris, no art. $10 \S 1^{\circ}$, o art. 152 da Constituição de 1937: “A sucessão de bens de estrangeiros situados no Brasil será regulada pela lei brasileira em benefício do cônjuge brasileiro e dos filhos do casal, sempre que não lhes seja mais favorável a lei do domicílio” (BRASIL, 1942).

Com a Constituição de 1946 o texto da LINDB veio a ser superado, com o art. 165 da CF/46 determinando que “a vocação para suceder em bens de estrangeiro existentes no Brasil será regulada pela lei brasileira e em benefício do cônjuge ou de filhos brasileiros, sempre que lhes não seja mais favorável a lei nacional do de cujus"8.

\footnotetext{
${ }^{7}$ Na Constituição de 1937 o princípio da lei mais favorável na sucessão ao cônjuge brasileiro e aos filhos do casal não figura como um direito fundamental, mas sim como parte integrante da ordem econômica nacional, no art. 152 (BRASIL, 1937), destoando, nesse aspecto, das demais Constituições.

${ }^{8}$ Amilcar de Castro denota que a redação do art. 165 da Constituição de 1946 era infeliz, "merecedora das mesmas censuras feitas ao art. 14 da antiga Introdução ao Código Civil” (CASTRO, 2004, p. 461), pois excluía a possiblidade
} 
Por sua vez, a feição atual existente no art. 5 XXXI, da CF/88 nasceu com a Constituição de 1967, a qual, em seu artigo 150, § 33 definia: “A sucessão de bens de estrangeiros, situados no Brasil será regulada pela lei brasileira, em benefício do cônjuge ou dos filhos brasileiros, sempre que lhes não seja mais favorável a lei nacional do de cujus”, redação não só repetida ipsis litteris no art. 5 $5^{\circ}$ XXI, da CF/88, mas também no art. $10 \S 1^{\circ}$ da LINDB, por força da Lei 9.047 de 18 de maio de 1995.

Doutrinariamente, o princípio da lei mais favorável tem sua origem na teoria geral das obrigações - mais precisamente no princípio de direito civil-comercial do favor negotii, pelo qual se procurava concretizar o objetivo da obrigação, que seria o seu adimplemento pela forma mais conciliadora entre as partes.

Ao transcender para o direito internacional privado, na concepção de lei mais favorável, o princípio assumiu a ideia de forçar o jurista ao convívio com a convergência de direitos decorrentes da diversidade legislativa quando diante da apreciação de questões de capacidade e validade, forçando uma aplicação do direito que fosse harmoniosa com a convergência de direitos ali existentes - como, por exemplo, o direito do foro, o direito da nacionalidade e demais direitos estrangeiros que eventualmente incidissem na obrigação em foco (VALLADÃO, 2015).

Cabe ressaltar que o princípio da lei mais favorável é um instrumento de conciliação entre diferentes direitos nacionais na hora da aplicação do direito ao caso concreto, de modo a promover uma maior justiça ao caso concreto, partindo das necessidades e peculiaridades que a relação jurídica em foco apresenta, e não um instrumento de defesa da ordem pública internacional.

Por essa razão, Haroldo Valladão foi um dos maiores defensores de sua adoção em matéria de sucessão, pois se trata de um princípio-elemento de conexão original do direito internacional privado, ao forçar o jurista a abrir sua mentalidade para os diferentes direitos envolvidos direta e indiretamente na relação jurídica e, na busca por justiça, realizar a aplicação do direito de forma mais harmoniosa possível nesta diversidade - daí ser um princípio caracterizado como progressista e evolutivo na compreensão e regulamentação, tanto de obrigações como da sucessão, na diversidade legislativa (VALLADÃO, 2015).

Portanto, não é temerário afirmar que, para a doutrina, a adoção do princípio da lei mais favorável na LINDB de 1942 foi um dos pouquíssimos louvores daquele diploma perante o sistema existente na ICC/1916. O avanço, contudo, parece ter se transformado em retrocesso, no momento

de se aplicar a lei do domicilio do de cujus, prendendo a sucessão na lex patriae do de cujus ou na lei nacional brasileira. 
em que se associou, constitucionalmente, com a ideia de direito fundamental ao cônjuge e filho brasileiro - hoje existente tanto em nível constitucional, como em nível infraconstitucional.

A essência do princípio da lei mais favorável é a de impor uma regra aberta, a qual demanda um fator interpretativo extranacional, forçando a inserção de elementos de direito comparado na análise das particularidades de cada relação jurídica para, ao fim, delimitar e estabelecer o direito mais justo para a mesma. Portanto, trata-se de "um complexo jogo hermenêutico que demanda a interpretação da norma de Direito Internacional Privado e a concomitante qualificação da questão, o estabelecimento dos elementos estrangeiros presentes” para “interpretar-se a lei eleita à luz do caso concreto que demanda a decisão” (MONACO, 2015, p. 56).

Em termos de sucessão, não se trata de preferir um herdeiro perante os demais por força de sua nacionalidade, mas de garantir que os herdeiros sejam tratados de forma equânime, pois o juiz, ao decidir a questão hereditária, teria de observar, além do último domicilio do de cujus, os outros elementos extranacionais existentes (como a nacionalidade dos herdeiros) e, a partir da conjugação desses elementos e direitos incidentes, optar pelo direito mais justo àquela sucessão.

Essa essência geradora de flexibilidade e equidade na aplicação do direito é incompatível com a noção de se tratar de um direito fundamental individual atrelado à determinada nacionalidade, pois esta última invariavelmente tem um caráter unilateral.

Dessa forma, fica evidente que houve um descompasso entre a compreensão doutrinária do princípio da lei mais favorável e seu tratamento legislativo. O que deveria se associar à equidade e ao direito considerado mais justo, acabou transformando-se numa espécie de benefício, um privilégio, uma proteção a mais para os cônjuges e filhos que gozam da nacionalidade brasileira, pois, in concreto, a ideia de diálogo de direito foi descartada e o favorecimento da aplicação do direito nacional acentuado.

\section{O PRINCÍPIO DA IGUALDADE ABSOLUTA DE DIREITOS ENTRE OS FILHOS: 0 § $6^{\circ}$ DO ART. 227 DA CF}

\subsection{A IGUALDADE DOS FILHOS NA CONSTITUIÇÃO FEDERAL DE 1988}

A Constituição brasileira de 1988 é produto de um longo processo de redemocratização cujo ápice foi a convocação de eleições gerais em 1986 para a formação de uma assembleia nacional constituinte. Não houve falta de participação popular e não houve outorga do texto, não sofrendo das mesmas particularidades da Grundgesetz. 
Entre os inúmeros avanços trazidos pela Constituição de 1988 o mais importante, para os limites deste estudo, foi a imposição da total e absoluta igualdade entre os filhos, rompendo uma tradição secular do direito civil brasileiro - a de discriminar os filhos entre legítimos e ilegítimos. Determinou o poder constituinte originário o fim dos regimes diferenciados até então existentes, sob a premissa de que o princípio da igualdade, "por ser um princípio fundamental, dita um limite de atuação do Estado e garante que a partir dele se promova a dignidade da pessoa humana, valor espiritual e moral inerente à pessoa” (ZENI, 2009, p. 70).

Sob a ótica da teoria de Bachof, não é temerário afirmar que o § $6^{\circ}$ do art. 227 da CF é uma norma constitucional material, que está em direta consonância com o fundamento, do Estado brasileiro, da dignidade da pessoa humana (art. $1^{\circ}$, III, da CF), e que também materializa o princípio da igualdade (art. 5 , caput, da CF) para a filiação.

A Constituição de 1988 impôs uma reforma radical, atualizando forçosamente a legislação infraconstitucional às novas realidades da sociedade brasileira, em especial o Código Civil de 1916, o qual "houvera sido, dentre outras razões citadas, elaborado para um país diferente, para um povo de costumes distintos, em diversa época, e em face de outros anseios e de outros valores” (LÔBO, 1999, p. 307).

Portanto, é um dispositivo que materializa como nenhum outro uma mudança de paradigmas, tornando sem efeito e, até certo ponto, inócua a distinção então vigente entre filhos legítimos (aqueles concebidos no seio da relação conjugal), filhos ilegítimos naturais (concebidos por pais solteiros), ilegítimos espúrios incestuosos e ilegítimos espúrios adulterinos (RODRIGUES, 2007, p. 66-67). Agora importa somente que é filho, não cabendo nenhuma forma de discriminação.

A radical mudança no tratamento dos filhos seria completamente sacramentada com o advento do Código Civil de 2002 (CC/2002), que, em seu art. 1.596, decretou o fim do apartheid legal que existia entre os filhos no direito brasileiro (LÔBO, 2014, p. 198-1.999).

Importa salientar que mesmo o advento da nova codificação civil não acabou com as dificuldades em se compreender a igualdade dos filhos, podendo-se destacar a situação criada pelo art. 1.841 do CC/2002, o qual define que, na concorrência à herança entre irmãos unilaterais e bilaterais, os bilaterais têm direito ao dobro do que têm direito os unilaterais, situação que, nas palavras de Maria Berenice Dias (2013, p. 47), é de flagrante inconstitucionalidade, por força da igualdade imposta aos filhos no texto constitucional de 1988.

O exemplo tem a finalidade de demonstrar que, ainda quando a lei parece estabelecer alguma distinção ou alguma omissão, a doutrina se comporta de forma a interpretar a questão em consonância ao princípio da igualdade, não havendo ressonância de teorias que promovam 
distinções discriminatórias ou prejudiciais para os filhos. Quaisquer antinomias que por acaso venham a surgir no sistema podem ser resolvidas pela regra da superioridade constitucional, sempre se procedendo à exclusão das possibilidades de interpretação consideradas inconstitucionais (MENDES, 1999, p. 230).

\subsection{O FILHO ESTRANGEIRO}

No Direito de Família brasileiro é perceptível que a doutrina, ao tratar a questão da filiação, não aparenta ter a mesma preocupação com a questão do filho estrangeiro.

Pela interpretação constitucional deveria dominar o entendimento da igualdade absoluta dos filhos, constituindo um absurdo considerar o filho estrangeiro como sendo "menos filho" do que o filho brasileiro, especialmente porque o princípio veda a discriminação e o tratamento diferenciado. Mas não se encontrou doutrina que afirmasse tal obviedade.

Normalmente o filho estrangeiro só surge na doutrina mainstream quando esta se propõe a analisar o art. $10, \S 1^{\circ}$, da LINDB e não quando analisa o art. $5^{\circ}$, XXXI, da CF. Basicamente, surge como uma figura en passant em matéria de sucessão, ficando à mercê do argumento de que, em relação so dispositivo da LINDB, “procura a lei brasileira proteger a família de nacionalidade brasileira” (VENOSA, 2015, p. 128).

Essa situação é estranha, pois por muito tempo a sucessão foi vinculada à nacionalidade do de cujus e não à nacionalidade dos herdeiros ou familiares:

\footnotetext{
O pattrimonio transmitido por via de successão constitue um todo, uma universitas, na qual se unifica a variedade das relações de direito. Esse complexo jurídico é a projecção economica da personalidade do fallecido, que se mantem emquanto se não effectua a partilha. Como projecção economica da personalidade de de cujus não póde o pattrimonio, encarado do ponto de vista do direito successorio, ter uma situação determinada, e, muitos menos, ter tantas sédes quantos fôrem os districtos jurisdiccionaes onde existirem immoveis. É, portanto, á lei pessoal do de cujus que ha de estar submettido o pattrimonio hereditario.

Depois o herdeiro é o representante, o continuador da pessôa do succedendo e, consequentemente, o complexo das relações de direito, que a successão envolve, deve ser regulado pela lei a que o de cujus estava submetido emquanto vivo (BEVILÁQUA, 2002 [1906], p. 276).
}

E a regra geral consagrada atualmente (art. 10, caput, da LINDB) é a do último domicílio do de cujus, afastando a nacionalidade como elemento de conexão, diferentemente de outrora. Basicamente, enquanto a doutrina internacionalista privatista apresenta tendência em prol de uma lenta desnacionalização do elemento de conexão da sucessão, a doutrina civilista aparentemente caminha em sentido contrário, utilizando-se da nacionalidade brasileira como argumento defensor do dispositivo, o qual não consagra a nacionalidade, mas sim o princípio da lei mais favorável. 
Uma explicação convincente sobre a aparente omissão jurídica, na doutrina brasileira, em torno do filho estrangeiro, pode ser explicada pelo apego excessivo de boa parte dos juristas brasileiros à retórica da soberania, sempre presente para restringir e preterir, no direito brasileiro, os estrangeiros em geral, como bem explica Cristiane Maria Lopes:

Costuma-se alegar ser a soberania o motivo das restrições ao [...] estrangeiro, justamente para não expor as verdadeiras razões políticas e econômicas que as determinam. Em outras palavras, a soberania, por si só, não seria fundamento suficiente, pois indica apenas o poder e não a efetiva decisão. Deixando de indicar a decisão (originada do poder), os Estados prendem evitar questionamentos quanto a eventuais abusos, evadindo-se de eventual controle por parte da comunidade internacional e dos padrões básicos de direitos humanos (LOPES, 2015).

Se a Constituição Federal de 1988 impôs “isonomia dos filhos, mais do que simplesmente igualar direitos patrimoniais e sucessórios”, traduzindo-se em "uma nova tábua axiológica, com eficácia imediata para todo o ordenamento” (TEPEDINO, 2008, p. 476), por que parte da doutrina ainda recorre à retórica da soberania na análise do art. 10, $\S 1^{\circ}$, da LINDB? E como fica a situação do filho estrangeiro diante dessa regra colisional que privilegia o filho brasileiro?

\section{A SITUAÇÃO CURIOSA ENTRE O ART. 5º, XXXI E O ART. 227, § $6^{\circ}$, DA CF}

\subsection{O PARADOXO ENTRE IGUALDADE DOS FILHOS E O PRINCÍPIO DA LEI MAIS FAVORÁVEL BASEADO NA NACIONALIDADE}

Nesses termos, o direito à herança, assegurado pela Constituição da República (art. 5º, XXX), há de ser regulamentado, interpretado e aplicado à luz dos princípios constitucionais, particularmente os da dignidade da pessoa humana, da liberdade e da solidariedade, permitindo a concreção dos objetivos da República, entre os quais se destacam o de construir uma sociedade livre, justa e solidária, e o de promover o bem de todos, sem preconceitos ou qualquer outra forma de discriminação (BARBOZA, 2008, p. 321-322).

É evidente que a situação curiosa envolvendo o art. 5º XXXI e o art. 227, § $6^{\circ}$, da CF é, em sua essência, um choque entre tradição e inovação no pensamento jurídico brasileiro. De um lado uma tradição, inócua em nossa opinião, estabelecida na crença no princípio da lei mais favorável como sendo um direito fundamental garantido aos filhos brasileiros na sucessão dos bens situados no Brasil, enquanto do outro lado encontra-se a radical mudança de paradigma na concepção da filiação e seu tratamento jurídico, rompendo uma tradição, até então secular, de distinções e regimes jurídicos diversos, quiçá discriminatórios.

Um paradoxo entre o novo e o tradicional. 
Porém, ambos os polos são normas constitucionais originárias - tanto o princípio da lei mais favorável, na sucessão, ao filho brasileiro, como a igualdade absoluta entre os filhos estão consagrados em normas constitucionais originárias - estão no texto constitucional desde a sua promulgação, em 1988. Diante dessa constatação, pode-se afirmar que seria este paradoxo um caso de norma constitucional inconstitucional na Constituição de 1988?

A resposta para essa questão não é simples. Para os limites deste estudo, formular uma resposta está na compreensão de dois núcleos que compõe a pergunta: (1) a natureza das normas constitucionais envolvidas e (2) a possível existência de elementos que possibilitem a hipótese de norma constitucional inconstitucional em uma delas.

\subsection{A NATUREZA DAS NORMAS CONSTITUCIONAIS ENVOLVIDAS}

A redação do art. 50, XXXI, da CF é um aperfeiçoamento da redação encontrada no art. 134 da Constituição de 1934 - não cabe afirmar que se trata de uma inovação da Constituição de 1988, mas tão somente uma reprodução da tradição legislativa até então existente (ou reprodução do texto de 1967). Do mesmo modo, a consagração do caráter de direito fundamental não advém de uma especialidade da Constituinte de 1988 - foi uma inovação da Constituinte de 1934.

Ocorre que, na história constitucional brasileira, é natural identificar momentos em que rompantes de nacionalismo permearam o espírito constituinte e estabeleceram regras que o manifestam, não sendo diferente com a Constituinte de 1988, na qual é perceptível o nacionalismo quando se analisam, principalmente, as regras sobre a ordem econômica, uma chamada "terceira faixa” que estava contaminada por traços de xenofobia e de retrocesso, oriundos da insegurança e dos receios de um país que então figurava entre os do terceiro mundo, "habitualmente indefesos e constantemente espoliados nas relações econômicas com os países da sociedade pós-industrial” (BONAVIDES, 2008, p. 490-491).

A Constituinte de 1988 não passou ilesa pela retórica da soberania nacional e sua tentação protecionista, podendo-se considerar a raiz do art. $5^{\circ}$, XXXI, da CF uma manifestação desse discurso.

Com auxílio da teoria de Bachof, não é temerário enquadrar o dispositivo como sendo uma norma constitucional formal; isto é, trata-se de uma norma constitucional que, por forças das circunstâncias envolvendo a criação da Constituição de 1988, manteve seu caráter constitucional, não possuindo um caráter especialíssimo, dado que na ordem jurídica brasileira já preexistia regra de conteúdo parecido - o art. 10, § $1^{\circ}$, da LINDB. 
O contraponto para essa análise sob a ótica de Bachof é a questão de o art. $5^{\circ}$, XXXI, da CF configurar uma cláusula pétrea, não sendo passível de abolição por imposição do próprio poder constituinte originário ao poder constituinte derivado, manifesto no art. 60 , § $4^{\circ}$, IV, da CF.

Aqui surge o grande problema em considerar o dispositivo como norma constitucional formal: cláusulas pétreas são consideradas “manifestação do núcleo imodificável, intangível e incontrolável dos valores consagrados” pelo constituinte originário, limitando a ação do poder reformador (VELOSO, 2003, p. 145-146).

Consequentemente, a teoria de Bachof seria inaplicável à classificação do dispositivo em foco, dado que sob o aspecto material ele não consagra nada de relevante. Porém, sendo considerado norma formal pela sistemática adotada pela Constituinte brasileira, tratar-se-ia de uma norma material, por força de ser integrante do núcleo axiológico da Constituição. Ou seja, seria uma norma constitucional material por força formal, situação que não encontra respaldo na teoria de Bachof, pois se trata de uma norma constitucional sui generis criada na realidade constitucional brasileira.

Por outro lado, o art. 227, $\S 6^{\circ}$, da CF é típica norma constitucional material, pois, como reiteradas vezes mencionado, positivou o princípio da igualdade dos filhos, rompeu tradições e impôs uma nova realidade ao direito de família brasileiro. É uma norma que consagra um valor social e que é parâmetro de validade e legitimação para as normas criadas em nível infraconstitucional. É uma norma material com conteúdo de metadireito, pois materializa um princípio (igualdade dos filhos), concretiza outro princípio (dignidade da pessoa humana) e estende, de forma harmônica, um terceiro (a igualdade). Mas interessa destacar, pela letra fria do art. 60, § $4^{\circ}$, da CF, que essa norma não é considerada uma cláusula pétrea, pois o poder constituinte derivado (reformador) pode alterar e, teoricamente, até abolir sua existência.

Surge outra complicação na adoção da teoria de Bachof: como pode uma norma com conteúdo de metadireito não configurar o núcleo axiológico da constituição? Tratar-se-ia de uma norma constitucional de natureza material, mas formal por causa da sistemática do texto constitucional?

Fica evidente que, sem a devida adaptação à realidade constitucional brasileira, a teoria de Bachof não pode ser utilizada como marco teórico para analisar a questão. Portanto, para fins deste estudo, a teoria será flexibilizada - considerar-se-á o art. 5º XXXI, da CF como uma norma constitucional formal, e o art. 227, $\S 6^{\circ}$, da CF uma norma constitucional material. 


\subsection{HIPÓTESE DE NORMA CONSTITUCIONAL INCONSTITUCIONAL?}

Na teoria de Bachof existem duas possibilidades de se enquadrar o fenômeno analisado como uma hipótese de norma constitucional inconstitucional: (1) a inconstitucionalidade em virtude de contradição com normas constitucionais de graus superiores e (2) a inconstitucionalidade por infração de direito supralegal positivado.

A primeira hipótese, da inconstitucionalidade em virtude de contradição com normas constitucionais de grau superior, parte da premissa de ser possível estabelecer critérios de hierarquia entre as normas envolvidas; significa que a partir do conteúdo de cada norma pode-se visualizar um critério de dominância entre elas. Trata-se de hipótese da qual surge a tentação em afirmar que a norma de conteúdo material seria superior à norma de conteúdo formal, incorrendo-se assim no equívoco de admitir o “paradoxo de uma lei violar a si mesma” (BACHOF, 1994, p. 58-59).

A solução para evitar incorrer nesse equívoco é simples. Basta lembrar que, na realidade constitucional brasileira, tanto o art. 50, XXXI, da CF como o art. 227, § $6^{\circ}$, da CF tem natureza sui generis, sendo que o caráter formal do primeiro e o material do segundo decorre da flexibilização da teoria de Bachof, a qual, por si, não possibilita estabelecer hierarquia entre ambos.

Mas, na busca por uma eventual dominância entre os dispositivos mencionados, pode-se socorrer na posição do STF na ADIn nº. 815-3 DF, em que o tribunal manifestou o entendimento de que "as cláusulas pétreas não podem ser invocadas para sustentação da tese de inconstitucionalidade de normas constitucionais inferiores em face de normas constitucionais superiores”, pois sua previsão é "apenas como limites ao Poder Constituinte derivado ou ao emendar a Constituição elaborada pelo Poder Constituinte Originário” (BRASIL, 1996).

Se por um lado o STF não tem competência para realizar controle de constitucionalidade em normas constitucionais originárias, por outro eliminou a possibilidade de estabelecer as cláusulas pétreas como um vetor de hierarquia entre normas constitucionais.

Por consequência, o posicionamento do STF acaba por invalidar a hipótese de inconstitucionalidade do art. 227, § $6^{\circ}$, da CF com fundamento de que o art. $5^{\circ}$, XXXI, da CF é cláusula pétrea e hierarquicamente superior.

Resta somente verificar, à questão, se é possível estabelecer um critério hierárquico entre os dois dispositivos a partir dos seus conteúdos, possibilidade que envolve a comparação entre o princípio da lei mais favorável e o princípio da igualdade absoluta dos filhos.

O princípio da lei mais favorável sempre foi considerado um princípio próprio do direito internacional privado, cuja existência reside em lidar com questões de incidência de vários direitos nacionais sobre uma determinada relação jurídica em concreto que apresenta elementos estrangeiros 
relevantes para sua apreciação. Trata-se de um princípio complementar, subsidiário, decorrente de um ramo jurídico auxiliar que é o direito internacional privado.

É um princípio indireto, adotado normalmente como critério de justiça/equidade em determinada situação dotada de elementos estrangeiros, não podendo ser associado com a ideia de que se trata de um produto oriundo de um direito fundamental ligado a determinada nacionalidade. Já o princípio da igualdade absoluta dos filhos, conforme mencionado, é um princípio material, norteador do instituto da filiação no direito de família brasileiro pós-Constituição de 1988 e o principal responsável pela grande transformação do conceito de filho no direito civil brasileiro nas últimas décadas.

É notório que, na contraposição dos dois princípios, aquele positivado no art. 227, § 6º da CF tem dominância sobre o outro, tornando inconstitucional a norma constitucional do art. 50, XXXI, da CF por estabelecer um critério de distinção entre os filhos baseado na nacionalidade dos mesmos, quando, pela própria concepção constitucional da filiação, a questão deve ser regida pela plena igualdade.

Saliente-se que essa linha de raciocínio não é isenta de críticas, especialmente por ignorar o problema da impossibilidade de se abolir um direito fundamental, bem como não foge do problema inerente à mensuração de princípios, situação que normalmente gera a tendência de se criar critérios não de hierarquia, mas de regra-exceção, na qual a igualdade dos filhos seria a regra geral e, por força de elementos in concreto, sua relativização em prol do filho brasileiro, desde que não gerasse discriminação, seria a regra-exceção.

A outra possibilidade de inconstitucionalidade de norma constitucional por via da teoria de Bachof para o caso em análise é a da infração de direito supralegal positivado na lei constitucional hipótese extremamente complexa, pois utiliza como parâmetro a figura do direito metapositivo, em que "uma norma jurídica que infrinja direito constitucional assim positivado será, portanto, simultaneamente «contrária ao direito natural» e inconstitucional" (BACHOF, 1994, p. 62).

Esse tipo de inconstitucionalidade é inaplicável no direito brasileiro contemporâneo. A inaplicabilidade decorre, justamente, das diferenças existentes entre a realidade da Grundgesetz e a realidade e a natureza da Constituição brasileira de 1988.

Em síntese, para se admitir tal modalidade de inconstitucionalidade tem-se de aceitar a possibilidade de se criar um parâmetro de legitimidade e obrigatoriedade jurídica das normas constitucionais; porém, como a Constituição de 1988 teve participação popular direta, seria contraditório ao próprio sentido de constituição criar tal parâmetro - o próprio princípio da unidade da constituição surge como obstáculo para essa modalidade de inconstitucionalidade. 


\subsection{A HIPÓTESE DE INCONSTITUCIONALIDADE DE NORMA CONSTITUCIONAL POR ERRO DO PODER CONSTITUINTE ORIGINÁRIO}

Se pela teoria de Bachof é difícil admitir a possibilidade de norma constitucional inconstitucional na curiosa situação existente entre o princípio da igualdade (absoluta) dos filhos e o princípio da lei mais favorável na Constituição de 1988, pelas particularidades da legislação brasileira pode-se visualizar uma outra (e controversa) possibilidade de inconstitucionalidade não visualizada por Bachof: a inconstitucionalidade por erro do poder constituinte originário.

Essa modalidade de inconstitucionalidade nasce de uma vulnerabilidade existente no princípio da unidade da constituição, normalmente ignorada por parte da doutrina e jurisprudência brasileira: o requisito de infalibilidade do poder constituinte originário na elaboração da constituição.

O princípio da unidade da constituição consiste na ideia de que a constituição não é um simples texto normativo, mas um "sistema interno unitário de normas e princípios” que obrigam “o intérprete a considerar a constituição em sua globalidade” de modo a conciliar "os espaços de tensão existentes entre normas constitucionais a concretizar", não podendo ser reduzida a "normas isoladas e fragmentadas” (CANOTILHO, 2003, p. 1.223-1.334).

Dessarte, toda lacuna ou conflito seriam meramente aparentes, devido ao fato de o sistema jurídico, em sua globalidade, dispor de meios para resolver essas tensões por si mesmo. Ocorre que esse pensamento pressupõe que os elementos componentes do sistema não estejam eivados de erro na sua elaboração.

Basicamente, a constituição, como qualquer lei ou norma jurídica, é texto, manifestação escrita da linguagem ou, nas palavras de Norberto Bobbio (2003, p. 72-73), proposições que consistem em "um conjunto de palavras que possuem um significado em sua unidade”, sendo a tarefa do jurista apreender, na interpretação da lei, seu significado (BOBBIO, 2003, p. 74).

Essa constatação permite estabelecer a premissa de que o poder constituinte originário não é tão ilimitado como a doutrina faz aparentar, devido ao fato de a construção do sistema jurídico obrigatoriamente estar sujeita às regras linguísticas (não jurídicas) para criação de uma ordem jurídica apta a reger uma sociedade, podendo-se destacar, entre essas regras, os quatros postulados da interpretação sistemática: a não contradição (Widerspruchsfreiheit), a não redundância (Nichtredundanz), a completude (Vollständigkeit) e a ordenação sistêmica (systematischen Ordnung) (PUPPE, 2011, p. 81).

Para o caso em foco, a inconstitucionalidade por erro do poder constituinte originário envolve uma possível violação do postulado da não contradição (Widerspruchsfreiheit), o qual 
determina a impossibilidade de existir, em um sistema, uma norma que viole a si mesma ou que contradiga o próprio sistema.

O raciocínio proposto parte da ideia de que, in abstrato, uma proposição “a” e sua negação “não a” são válidas, mas quando postas em um sistema, existe a necessidade de o sistema estabelecer um critério para determinar quais dessas proposições nele continuam válidas, o que seria uma proposição “x”, esta pressuposta como válida no sistema (PUPPE, 2011, p. 82).

Dessarte, se existe uma norma “igualdade” e uma norma "não igualdade” em um mesmo sistema, ambas só poderão ser válidas se o próprio sistema estabelecer uma ponderação para a validade dessas normas contraditórias ${ }^{9}$. Existindo essa ponderação, estar-se-á diante do sistema regra-exceção; não existindo, haverá ocorrência de erro do poder constituinte originário, e uma das normas será inconstitucional.

É tentador estabelecer o princípio da lei mais favorável do art. 5 , XXXI, da CF como uma exceção ao princípio da igualdade (art. 5º caput, da CF) e, por consequência, exceção ao princípio da igualdade (absoluta) dos filhos (art. 227, § $6^{\circ}$, da CF) - pensamento que mantém a harmonia no texto constitucional e, aparentemente, resolveria a tensão em foco, tornando-a um pseudoproblema, pois existe a ponderação representada pelo princípio da isonomia (art. $5^{\circ}$, caput, da CF) e a inconstitucionalidade por erro seria hipótese absurda.

Ocorre que essa posição cômoda não condiz com a sistemática que ambos os dispositivos exercem no ordenamento jurídico brasileiro. A primeira crítica é que o princípio da lei mais favorável foi inserido no direito constitucional antes mesmo do princípio da igualdade dos filhos - o primeiro surgiu, constitucionalmente, em 1934, e sua feição contemporânea é um mero melhoramento da redação originada em 1967, enquanto o segundo somente surgiu com a Constituição de 1988.

Cronologicamente, a exceção surgiu antes da regra. O princípio da igualdade dos filhos não se confunde com o princípio da isonomia geral, pois este último já existe desde a Carta Magna Imperial de 1824, enquanto que a igualdade dos filhos não.

A segunda crítica é a fragilidade em conceber o princípio da lei mais favorável como exceção da isonomia, pois constitucionalmente o princípio desenvolveu um caráter unilateral e protetivo para a figura do filho brasileiro, diferente da natureza cosmopolita que este princípio tem na doutrina do direito internacional privado, sendo mais provável associá-lo ao campo da ordem pública internacional brasileira, pois tanto sua inserção quanto consagração constitucional

\footnotetext{
${ }^{9}$ Em linhas gerais seguem-se as regras sobre colisões entre regras, princípios e princípios-regras em Theorie der Grundrechte, de Robert Alexy.
} 
ocorreram em períodos de rompante nacionalista (1934) e de caráter autoritário (1967), tanto que a própria abordagem sobre o filho estrangeiro na doutrina nacional é, praticamente, inexistente, embora sempre haja menção de proteção à família brasileira, quando o art. 5 XXXI, da CF e o art. 10, § $1^{\circ}$, da LINDB são analisados.

A derradeira crítica que se pode fazer é a de que o critério de ponderação nessa questão não é a isonomia, mas sim o princípio da dignidade da pessoa humana, pois quando se verifica o fundamento do surgimento da igualdade da filiação no art. 227, § 6º da CF, não se está diante de isonomia, mas de promoção da dignidade da pessoa humana - algo consagrado no art. $1^{\circ}$, III, da CF pela primeira vez na história constitucional brasileira e positivado como um dos princípios fundamentais.

Dessarte, a inovação da igualdade entre os filhos surgiu em conjunto com a novidade da consagração da dignidade da pessoa humana como princípio fundamental, não pela promoção ou ampliação do princípio da isonomia, princípio já existente nos textos constitucionais anteriores a 1988.

Se o vetor da ponderação for a dignidade da pessoa humana, fica evidente que existe uma anomalia na tradição de beneficiar o filho brasileiro diante da sistemática da igualdade entre os filhos que proíbe distinções. Trata-se da exposição de um equívoco que o poder constituinte originário cometeu: a manutenção da tradição de proteção ao filho baseada na nacionalidade brasileira e, ao mesmo tempo, a imposição da igualdade dos filhos, proibindo qualquer discriminação - nesse entendimento, existe a violação do postulado da não contradição, pois o art. 5 , XXXI, da CF viola a diretriz imposta pela dignidade da pessoa humana na promoção da igualdade dos filhos.

Essa possibilidade de equívoco por parte do poder constituinte de 1988 não é algo inesperado, devido à própria natureza daquela Assembleia Constituinte, bem como à própria natureza do texto constitucional de 1988, pois, como bem lembram Paulo Bonavides e Antônio Paes de Andrade, “a promulgação da Carta, tendo-se em vista a amplitude de seu conteúdo”, é tão somente o "encerramento de uma fase digna sem dúvida de festejar-se, mas que de modo algum preenche toda a tarefa formuladora do nosso ordenamento, assentado sobre as bases do estado de Direito” (BONAVIDES; ANDRADE, 2008, p. 503).

Por fim, cabe alertar que, mesmo que se considere como vetor de ponderação a isonomia e se estabeleça a dinâmica da regra-exceção, mantendo-se o princípio da lei mais favorável com base na nacionalidade brasileira do filho, serão gerados problemas de estabilidade do elemento de conexão. 
Em uma sociedade cada vez mais globalizada, com o aumento do fenômeno da dupla nacionalidade, os elementos de conexão baseados em nacionalidade tendem a apresentar o problema de previsibilidade. O primeiro problema técnico dessa situação está na questão da sucessão de bens de estrangeiros no Brasil, podendo haver concorrência entre um filho com dupla nacionalidade e um filho estrangeiro. Considere-se que esse filho de dupla nacionalidade não venha ao Brasil durante anos e que tenha domicílio no exterior, enquanto que o filho estrangeiro resida e seja domiciliado no Brasil. Parece razoável aplicar a previsão do art. 5º XXXI, da CF? A aplicação não tornaria o art. $5^{\circ}$, XXXI, da CF inconstitucional, por violar, justamente, a isonomia?

Outro problema técnico decorrente da associação com a nacionalidade é a questão da lei pessoal do de cujus, problema que se desdobra em dois: (1) seria a lei pessoal a lei do domicílio do de cujus? Ou (2) seria a lei pessoal a lei da nacionalidade do de cujus? Se for a lei da nacionalidade, como resolver o problema no caso de o de cujus possuir dupla nacionalidade? Qual nacionalidade prevaleceria?

Enfim, essas questões de ordem técnica, próprias do direito internacional privado, não foram abarcadas pelo poder constituinte da Constituição de 1988, tornando possível essa curiosa situação no rol dos direitos fundamentais.

\section{CONSIDERAÇÕES FINAIS}

Conclui-se que a curiosa situação entre o art. 5 XXXI, da CF e o art. 227, § 6 ${ }^{\circ}$, da CF continua aberta a interpretações sobre ser ou não um caso de norma constitucional inconstitucional na Constituição Federal de 1988. A única certeza é a de que a teoria de Bachof não é aplicável para o caso e, muito menos, possibilita certeza em se verificar se é um caso de inconstitucionalidade de norma constitucional.

Em nossa opinião, essa situação curiosa só pode ser considerada uma hipótese de inconstitucionalidade se admitida a existência de erro por parte do constituinte de 1988 na elaboração da Constituição.

Nossa opinião se fundamenta em duas deduções do presente estudo: primeira, que o legislador simplesmente melhorou a redação do texto constitucional de 1967, mantendo o caráter nacionalista no que deveria ter um caráter cosmopolita, basicamente simplificando um princípio extremamente complexo e envolvido com a ideia de ius communis, como é o da lei mais favorável, com uma interpretação simplista e nacional-protetora; e, a segunda, decorre do fato de que tal manutenção acabou gerando uma distorção ante a inovação da igualdade entre os filhos, parecendo 
mais um caso em que a legislação de direito internacional privado se manteve intacta enquanto o direito material sofreu profundas alterações.

Também se espera ter evidenciado que existe uma ampla e geral negligência no direito de família brasileiro quanto à questão do filho estrangeiro, gerando um descompasso entre a doutrina do direito internacional privado e a do direito civil no que diz respeito ao seu tratamento nos casos de sucessão de bens no Brasil. Enquanto no direito internacional privado predomina o discurso cosmopolita e a busca pelo "melhor direito", na doutrina civil é rotineira a utilização do argumento nacionalista de proteção aos nacionais em face dos não nacionais.

Por fim, mesmo não podendo ter certeza de se tratar de um caso de norma constitucional inconstitucional, pode-se ter certeza de que existe uma tensão entre esses dois dispositivos, demonstrando uma real necessidade de se promover uma reinterpretação do princípio da lei mais favorável, restabelecendo seu caráter cosmopolita, bem como uma revisão da ideia de que a nacionalidade é a base para um tratamento diferenciado em matérias de direito internacional privado.

\section{REFERÊNCIAS}

ALEMANHA. Gesetz zu dem Vertrag vom 31. August 1990 zwischen der Bundesrepublik Deutschland und der Deutschen Demokratischen Republik über die Herstellung der Einheit Deutschlands - Einigungsvertragsgesetz - und der Vereinbarung vom 18 September 1990. Bundesgesetzblatt Nr. 35/1990, 28 de setembro de 1990, p. 885-1.245. Disponível em: <www.bgbl.de>. Acesso em: 21 jun. 2015.

. Grundgesetz für die Bundesrepublik Deutschland. Bundesgesetzblatt Nr. 1. Bonn: 23 de maio de 1949, p. 1-19. Disponível em: <www.bgbl.de>. Acesso em: 21 jun. 2015.

. Lei Fundamental da República Federativa da Alemanha. Trad. Assis Mendonça. Editora do Parlamento alemão, 2011. Disponível em: <https://goo.gl/3YUBML>. Acesso em: 24 jul. 2015.

BACHOF, Otto. Normas constitucionais inconstitucionais? Trad. J. M. Cardoso da Costa. Coimbra: Almedina, 2008.

. Normas constitucionales inconstitucionales? Lima: Palestra Editora, 2010. Disponível em: <http://goo.gl/icBn9k>. Acesso em: 24 jul. 2015.

BARBOZA, Heloisa H. Aspectos controversos do direito das sucessões: considerações à luz da Constituição da República. In: TEPEDINO, Gustavo (Org.). Direito civil contemporâneo: novos problemas à luz da legalidade constitucional: anais do congresso internacional de direito civilconstitucional da cidade do Rio de Janeiro. São Paulo: Atlas, 2008. 
BAYERISCHE STAATSBIBLIOTHEK. Besatzungsstatut zur Abgrenzung der Befugnisse und Verantwortlichkeiten zwischen der zukünftigen deutschen Regierung und der Alliierten Kontrollbehörde, 10. Mai 1949. Disponível em: <http://goo.gl/c0lTtM>. Acesso em: 19 jun. 2015.

BEVILÁQUA, Clóvis. Direito Internacional Privado. Campinas: RED Livros, 2002.

BOBBIO, Norberto. Teoria da norma jurídica. Trad. Fernando P. Baptista e Ariani Bueno Sudatti. 2. ed. Bauru: Edipro, 2003.

BONAVIDES, Paulo. História constitucional do Brasil. Brasília: OAB Editora, 2008.

BRASIL. Consolidação das Leis Civis: publicação autorisada pelo govêrno. 3. ed. Rio de Janeiro: B. L. Garnier, 1876.

. Constituição da República dos Estados Unidos do Brasil. 16 de julho de 1934. Portal da Legislação: Constituição. Disponível em: <http://goo.gl/dYNCTM>. Acesso em: 15 jul. 2015.

- Constituição da República Federativa do Brasil de 1988. Portal da Legislação: Constituição Federal. Disponível em <http://goo.gl/zaRrL>. Acesso em: 19 jun. 2015.

Constituição da República Federativa do Brasil. 24 de janeiro de 1967. Portal da Legislação: Constituição. Disponível em: <http://goo.gl/Be70Ry>. Acesso em: 15 jul. 2015.

. Constituição dos Estados Unidos do Brasil. 10 de novembro de 1937. Portal da Legislação: Constituição. Disponível em: <http://goo.gl/O4zZYV>. Acesso em: 20 set. 2015.

. Constituição dos Estados Unidos do Brasil. 15 de setembro de 1946. Portal da Legislação: Constituição. Disponível em: <http://goo.gl/IjgQK>. Acesso em: 15 jul. 2015.

. Decreto-lei $n^{\circ}$. 1.608, de 18 de setembro de 1939. Código de Processo Civil. Portal da Legislação: Decretos-leis. Disponível em: <http://goo.gl/DQsvxm>. Acesso em: 20 ago. 2015.

. Decreto-lei $n^{\circ}$.4.657, de 4 de setembro de 1942. Lei de Introdução às Normas do Direito Brasileiro. Portal da legislação: Leis. Disponível em: <http://goo.gl/trUp5>. Acesso em: 2 jun. 2015.

. Lei $n^{\circ}$. 3.071, de 1 de janeiro de 1916. Código Civil dos Estados Unidos do Brasil. Portal da Legislação: Leis. Disponível em: <http://goo.gl/pQIqfP>. Acesso em: 17 jun. 2015.

. Lei $n^{\circ}$. 5.869, de 11 de janeiro de 1973. Institui o Código de Processo Civil. Portal da Legislação: Leis. Disponível em: <http://goo.gl/Rw3qT>. Acesso em: 15 jul. 2015.

. Supremo Tribunal Federal. Ação Direta de Inconstitucionalidade $n^{\circ}$. 815-3 DF. Governador do Estado do Rio Grande do Sul e Congresso Nacional. Tribunal Pleno do Supremo Tribunal Federal, Diário da Justiça, 10 maio 1996. Disponível em: <http://goo.gl/kmaz48>. Acesso em: 8 jul. 2015.

CANOTILHO, José J. G. Direito Constitucional. 7. ed. Coimbra: Almedina, 2003. 
CASTRO, Amilcar de. Direito internacional privado. 5. ed. Rio de Janeiro: Forense, 2004.

DIAS, Maria B. Manual das sucessões. 3. ed. São Paulo: Revista dos Tribunais, 2013.

ESTRELLA, André L. C. Normas Constitucionais inconstitucionais. Disponível em: <http://goo.gl/1lJVRQ>. Acesso em: 3 jun. 2015.

FERNANDES, Leonardo. A inconstitucionalidade de normas constitucionais originárias e a ADI 815-3. In: Observatório da Jurisdição constitucional. Brasília, ano 2, out. 2008. Disponível em: $<$ http://goo.gl/VUu3eB>. Acesso em: 4 jun. 2015.

LÔBO, Paulo L. N. Direito Civil: Famílias. 5. ed. São Paulo: Saraiva, 2014.

. O ensino do direito da família no Brasil. In: Wambier, Tereza A. A.; LEITE, Eduardo de O. (Coord.). Repertório de doutrina sobre direito de família. São Paulo: Revista dos Tribunais, 1999.

LOPES, Cristiane M. S. O direito à não discriminação dos estrangeiros. In: Boletim Científico ESMPU. Brasília, ano 11, n. 37, p. 41. Disponível em: <http://goo.gl/HPBrTK>. Acesso em: 17 jul. 2015.

MENDES, Gilmar F. Jurisdição constitucional: o controle abstrato de normas no Brasil e na Alemanha. 3. ed. São Paulo: Saraiva, 1999.

MIRANDA, Pontes de. Tratado de Direito Internacional Privado - Parte Especial. Tomo II. Rio de Janeiro: José Olympio, 1935.

MONACO, Gustavo F. de C. Problema hermenêutico da lei mais favorável em direito internacional privado à luz do desafio kelseniano. In: Revista IMES. Disponível em: <http://goo.gl/mZTDaE> . Acesso em: 15 jul. 2015.

NEVES, Marcelo. Teoria da inconstitucionalidade das leis. São Paulo: Saraiva, 1988.

PUPPE, Ingeborg. Kleine Schule des juristischen Denkens. 2. ed. Vandenhoeck \& Ruprecht: Göttingen, 2011.

RODRIGUES, Silvio. Direito Civil: direito das sucessões - vol. 7. 26. ed. São Paulo: Saraiva, 2007.

SIEYÈS, Emmanuel J. Qu'est-ce que le Tiers-État? 3. ed. [sem editora]. França: 1789. Disponível em: <http://goo.gl/06RrDM>. Acesso em: 20 ago. 2015.

STRECK, Lenio L. A recepção teórica inadequada em terrae brasilis. Revista direitos fundamentais \& democracia (UniBrasil), v. 10, p. 2-37, 2011.

; BARRETTO, Vicente de P.; OLIVEIRA, Rafael T. de. Ou lado B. Normas constitucionais inconstitucionais. Consultor Jurídico de 19 de julho de 2009. Disponível em: <http://goo.gl/998A1X>. Acesso em: 3 de junho de 2015.

TEPEDINO, Gustavo. Temas de direito civil. 4. ed. Rio de Janeiro: Renovar, 2008. 
VALLADÃO, Haroldo. O princípio da lei mais favorável no DIP. In: Revista da Faculdade de Direito da USP. Disponível em: <http://goo.gl/HfS5Ar>. Acesso em: 15 jul. 2015.

VELOSO, Zeno. Controle Jurisdicional de constitucionalidade. 3. ed. Belo Horizonte: Del Rey, 2003.

VENOSA, Sílvio de S. Direito civil: direito das sucessões (vol. 7). 15. ed. São Paulo: Atlas, 2015.

ZENI, Bruna S. A evolução histórico-legal da filiação no Brasil. In: Revista Direito em Debate. Ano XVII, no. 31, p. 70, jan-jun 2009. Disponível em: <https://goo.gl/21Jjvn>. Acesso em: 17 jul. 2015.

\title{
UNCONSTITUTIONAL CONSTITUTIONAL NORMS? THE CURIOUS CASE OF ARTICLE 5 ${ }^{\text {TH }}$, CLAUSE XXXI, AND ARTICLE 227, § 6, OF THE 1988 BRAZILIAN CONSTITUTION
}

\begin{abstract}
The paper tries to analyze the curious relationship between the constitutional most favorable law principle adopted in relation to the succession of foreign assets located in Brazil (art. $5^{\circ}$, cl. XXXI) and the Equal Protection Clause as guiding rule for Children's Legitimacy (art. 227, § 6), as a case of unconstitutional constitutional norm in the Brazilian Federal Constitution. It seeks to understand the emergence of the theory of unconstitutional constitutional norms, paying special attention to the theory of Otto Bachof and to the manifested position of the Brazilian Supreme Federal Court (STF) in the Direct Unconstitutional Action (ADIn) \#815-3 DF. It also seeks to understand how the most favorable law principle became a fundamental right in the Brazilian constitutional tradition as well as the consequences of the application of Equal Protection Clause to Children's Legitimacy by the current Constitution. At the end, it will try to indicate the elements that make this curious situation a case of unconstitutional constitutional norm in Brazil.
\end{abstract}

\section{KEYWORDS}

Unconstitutional constitutional norms. Equal Protection Clause (Children's Legitimacy). Most favorable law principle. Conflict of law (private international law). 